(46)

\title{
3. 手術創内異物残留防止対策
}

開胸, 開腹手術などで時に術中に体腔内や組 織間隙に手術用器材やガーゼなどを残留すると いう事故が発生するが，このような事故は絶対 に起してはならない事故の一つである。その予 防法として従来とられて来た方法は，(1) 術前 後に数量を点検する方法，（2）注意力を主体と してガーゼに標識をつけて判別を易くし誤入を 防ぐ方法，（3）レントゲン線によって識別可能 なガーゼを使用し術直後レントグンの透視また は撮影によって予防する方法である.

前二者は過去ほとんどの病院で実施されて来 た方法であるが，最近のように手術室勤務者の 人手不足が慢性化すると仲々確実に実施するこ とができなくなったのみならず，この方法は あくまで人間の注意力や計算に依存するもので 絶対性は保証されない。

これに対しレントゲン線を用いる方法は，用 いた器具がすべてレントゲン線で造影可能なも
広島大学医学部附属病院手術部

芦山辰朗

のであるならば点検もれのない絶対確実な方法 である、しかしながらこの方法は老若男女をと わず無差別に放射線を浴びるという極めて極端 な不利な方法でもある。外科用イメージによる 透視でも $0.2 \mathrm{r} /$ 分から $0.5 \mathrm{r} /$ 分, 撮影で 1 回 $25 \mathrm{mr}$, 胸部直接撮影 1 回で骨髄換算線量 $4.6 \mathrm{~g}$-rad 平均 の被爆になる. 特に問題になるの渃年者の骨 髄積算線量掞よび生殖線量である。また胎児の 白血病や妊娠時の被爆も重大な問題になり，妊 娠が確立してから出産までに下腹部に $1 \mathrm{rem}$ を 越えてはならないとされている１ rem はほぼ $1 \mathrm{rad}$ に当り 1 回の腰椎撮影線量に等しい。 そ こで線量を可能な限り制限した装置の仕様を実 際に追求したところ, 術後 1 回の点検に従来の 方法で $10^{-3} \mathrm{r}$ レベルのものを $10^{-6} \mathrm{r}$ にまで減少 さすことが可能であった.この線量では写真の フィルムが感光しない程度である.

\section{4. 手術室の消毒法に関する検討}

東京大学医学部附属病院中央手術部

○小林宽伊 林キイ子

伊 勢 義 男 都 築 正和

Bioclean Room において手術を行なうこと により，術中污染を防止することに関する検討 がさかんであるが，臨床上，どこまで無菌管理 が必要かという点も，なかなか結論を下し得な い. いずれにせよ, 現状は, 従来の空調による 手術室が大部分であり，このような手術室にお
いては, 空調による乱流により, 休, 壁の細菌 がまい上り，術野を污染する危険性がある。そ こで，この点に関し検討を行なった.

方 法

断面積 $10 \mathrm{~cm}^{2}$ の金属の円筒に, 血液寒天培地 を流し込み，血液寒天円柱培地 (Blood Ager 